\title{
KNSTRN wt Allele
}

National Cancer Institute

\section{Source}

National Cancer Institute. KNSTRN wt Allele. NCI Thesaurus. Code C119653.

Human KNST RN wild-type allele is located in the vicinity of $15 q 15.1$ and is approximately $12 \mathrm{~kb}$ in length. This allele, which encodes small kinetochore-associated protein, is involved in the metaphase/anaphase transition of the mitotic cell cycle. 